\title{
A VEZETÉSTUDOMÁNY VISELKEDÉSKUTATÁS-CENTRIKUS MEGKÖZELÍTÉSE A HUMÁNETOLÓGIA TÜKRÉBEN
}

A szerző eredeti ötletre épülő kutatása a sajátos megközelítés révén magas hozzáadott értékkel kecsegtet a vezetéstudomány világában. Jelen cikk egy $\mathrm{PhD}$ disszertáció részbeni absztrakciója, mely az újszerü gondolkodásmódban rejlő lehetőségek kihasználására szeretné felhívni a figyelmet. A vezetéstudomány és a viselkedéskutatással foglalkozó diszciplínák szerves egésszé kapcsolása a gyakorlatban is alkalmazható modelleket eredményezett.

"A bölcs ember a természet rendje szerint él és cselekszik."

Lao-ce

Körülbelül négy és fél milliárd évvel ezelőtt kialakult egy kicsiny, barátságos bolygó, a Föld. Az elmúlt hatszázmillió év során felszínének hőmérséklete lehetővé tette a legkülönfélébb életformák megjelenését. Ezalatt több mint egymillió állat- és csaknem félmillió növényfaj fejlődött ki. Később azonban az egyik állatfaj fokozatosan átvette az uralmat a többi élőlény fölött. Ez a kis termetű emberszabású szakított régi életmódjával, hátsó lábaira állt, és beszélni kezdett.

Vajon mi lehet a Homo sapiens, a „bölcs ember” páratlan sikerének a titka? Milyen mozgatórúgók húzódnak cselekedetei mögött? Hogyan lehetne a faj, és saját magunk viselkedését magyarázni?

Ilyen, és hasonló kérdések már régóta foglalkoztatják az emberiséget. Számos tudomány - mint a filozófia, pszichológia, antropológia, szociológia meglehetôsen sokféleképpen igyekezett választ találni a „nagy kérdésekre”. Az erőfeszítések ellenére maradtak fehér foltok, és úgy tünik egyre nagyobb igény mutatkozik a sokszor izolált eredmények egyfajta szintézisére.

A válasz megtalálásához úgy tűnik figyelembe kell vennünk - az utóbbi időben - a viselkedéskutatásban átütő sikereket produkáló természettudományos eredményeket is. Az etológia, az evolúcióbiológia és a ge- netika mind-mind olyan felfedezésekkel lepték meg a világot, melyeket más területek kutatói is örömmel üdvözöltek.

$\mathrm{PhD}$ disszertációmban összefoglalt kutatásaimmal egyrészt szeretnék hozzájárulni a viselkedéskutatásban napjainkra felhalmozott, különböző tudományterületek ismeretanyagának szintéziséhez, másrészt szeretném visszaállítani azt a kissé megbillent egyensúlyt, amely az emberi viselkedés kutatóit a múltban gyakran a helyi szokások, hagyományok és számtalan eltérés vizsgálatára késztették.

Meggyőződésem, hogy a felszíni különbségek sokszor túlzott - kiemelése elhomályosíthatja a mélyen gyökerező, az emberi viselkedés tanulmányozásánál nagy jelentőséggel bíró hasonlóságokat. Globalizálódó világunkban ez talán még kiemeltebb figyelmet érdemel.

Az emberi természet, evolúciós gyökerekből táplálkozó genetikai örökségének munkahelyi sajátosságait vizsgáló kutatásaim, a vezetéstudományi szempontból is értékelhető tényezők feltárására irányulnak.

Bízom benne, hogy az eredmények birtokában, az emberi természet sajátosságainak, lélektani összefüggéseinek alaposabb megismerésével és figyelembevételével teljesíthetővé válik a hatékonyabb munkavég- 
zés és a kellemesebb munkahelyi légkör megteremtésének kettős célja.

$\mathrm{Az}$ ily módon feltárt ismeretanyag egy másik szempontból is üdvözítő lehet. Gyorsan változó világunkban ritkaságszámba mennek a viszonylag állandónak tekinthető, relatíve hosszú távon érvényesülő felfedezések. Az emberi természetre - a környezeti tényezők mellett - sokszor döntő hatással lévő genetikai komponensek pedig - az evolúció konzervatív természete és lassú folyamata miatt - éppen ezek közé sorolhatók, így a magunk és munkatársaink viselkedését befolyásoló genetikai tényezők hatása még sok-sok generáción át kimutatható lesz.

A vezetéstudomány humánetológiai nézőpontból történő vizsgálata újszerū ötletre épülő, meglehetősen komplex kutatási folyamat.

A humánetológia evolúciós tudomány, feltételezi, hogy az emberi viselkedés az evolúció terméke, az ember környezethez történő adaptációjának az eredménye. Természetesen elismeri, hogy az emberi viselkedésben óriási szerepet játszik a tanulás, a tradíciók és a kultúra, de azt vallja, hogy a kultúrára való képesség az evolúciós folyamat eredménye és a lehetséges kultúrák szerkezete, dinamikája is genetikai korlátok között alakul ki. A humánetológia a kultúrát mint viselkedési rendszert fogja fel, szem előtt tartva, hogy a kultúra komponensei tanulási folyamatokban alakulnak ki, de mint viselkedésmintázatok, alkalmasak etológiai és evolúciós elemzésre. A tulajdonságok mindig kettős, genetikai és környezeti befolyás alatt nyilvánulnak meg. Az állatoknál az ökológiai környezet szerepe a döntő, míg az ember esetében a kultúra az a környezet, amely viselkedését döntően befolyásolja. Humánetológiai vizsgálatoknál ezeket a tényezőket (mindkettőt) mindig igyekszünk megtalálni, és kölcsönhatásukat kimutatni.

A humánetológia mint az etológia részterülete, elsősorban etológiai módszerek alkalmazásával és az etológiában kifejlesztett elméleti eszközök segítségével vizsgálja az emberi viselkedést, az ember természetes környezetében, a társadalomban. Célja, a legszélesebben értelmezett emberi adaptáció tudományos vizsgálata. Ehhez nemcsak az etológia, hanem más, az emberrel vagy viselkedésével foglalkozó tudományok, így a szociológia, a pszichológia, az antropológia, a kulturális antropológia, a néprajz, a gazdaságtan, a filozófia, a történelemtudomány, a művészetek, az etika, az esztétika, a politológia és az új határtudományok eredményeit és eszközeit is igénybe veszi. (Csányi, 2000)

Kutatási tevékenységem kezdete előtt azon tűnődtem, hogy a viselkedéskutatás humánetológiai gondol- kodásmódja és a vezetéstudomány emberi tényezői, a vezetéslélektan, valamint ezek együttes vizsgálata milyen szervezeti körülmények között hasznosítható eredményekkel kecsegtethet. Arra a következtetésre jutottam, hogy a humánetológia emberi természetet, viselkedést magyarázó, evolúciós gyökerekből táplálkozó - a pszichológiában is hiánypótló - eredményei biztosan hasznosíthatók lennének valamilyen módon a vezetéstudomány világában is. Az emberi természet, magatartásunk mozgatórugóinak mélyebb, hitelesebb megismerésével, majd ezek munkahelyi, szervezeti körülmények közötti figyelembevételével - véleményem szerint - nemcsak hogy növelhető az egyéni, a csoport, s ez által a szervezeti teljesítmény is, hanem a természetünkhöz, genetikai örökségünkhöz jobban igazodó munkakörülmények kialakításával egyaránt javítható a saját magunk, szervezeti, illetve munkahelyi közérzetünk, valamint növelhető a munkával való megelégedettségünk is. Ez pedig az az „öröm kategória”, amely főnöknek és beosztottnak egyszerre lehet sajátja.

Először igyekeztem megtalálni azokat a humánetológiában eddig már sikeresen feltárt - de nem szervezeti, hanem általános körülményekre vonatkozó területeket, amelyek további interdiszciplináris felfogású vizsgálata a vezetéstudományon belül is értelmezhető szegmenseket jelenthet. Véleményem szerint ezek mélyreható, szervezeti körülmények közötti kutatása képes új, előremutató, a vezetéstudomány területén hasznosítható olyan információkkal, eredményekkel, módszerekkel szolgálni, melyek társadalmi jelentősége sem elhanyagolható.

Az új ötletekre épülő logika alapján a kutatási területeket három fő csoportra, és azokon belül két-két (összesen hat)' alcsoportra bontottam:

Kötődéssel kapcsolatos vizsgálati területek:

Kontaktusok

Kötődési kapcsolatok

Csoportra, csoportszerkezetre irányuló vizsgálatok:

Csoportszerkezet

Szinkronizáció

\section{Dominancia, hierarchia:}

Agresszió

Rangsor, dominancia és szabálykövetés

A vizsgálatok „,mélységi” igényének kielégítése és a téma előzőekben vázolt interdiszciplinaritása egyértelműen indokolta a mindkét területen használatos kutatási módszerek komplementer jellegű alkalmazását. Ennek megfelelően megfigyelések, önkitöl- 
tős és megkérdezéses kérdőívek, valamint egy, a KFKI-nál készített esettanulmány is a módszertani repertoár részét képezte. A Miskolci Egyetemet és a KFKI Számítástechnikai cégcsoportját érintő empirikus kutatás - a teljesség igénye nélkül - az alábbi eredményekkel szolgált.

A három nagy kutatási terület hat részegységének vizsgálata számos, tipikusan szervezeti körülmények között megnyilvánuló fajspecifikus emberi viselkedésjegyet tárt fel.

A rendkívül változatos kontaktusformák munkahelyi előfordulási gyakorisága, mélyen bennünk élő genetikai örökségre vezethető vissza. Az ember ,,társas lény" voltát bizonyító tényezők, viselkedésjegyek ismerete, valamint térnyerésük biztosítása a vezető(k) és a beosztottak közös érdeke.

A primátákra is jellemző hím-hím kapcsolatok a férfiak olykor elkülönült munkavégzésénél, intézményen belüli és kívüli csoportosulásainál is tetten érhetők.

A férfikötődés és a férfiak tradicionális vezető szerepe - a társadalmi élet egyéb területeihez hasonlóan - az egyetem szervezeti egységeinél is szignifikánsan kimutatható.

A már oly sokféleképpen vizsgált csoportszerkezet viselkedéskutatási aspektusai - a humánetológiában összegzést nyert antropológiai, szociológiai és pszichológiai eredményekre támaszkodva - a természetés társadalomtudományos eredményeket is figyelembe vevő létszám-intervallumok meghatározásához vezettek.

A munkahelyi-baráti informális kapcsolatok elhatárolható létszám-intervallumait feltáró kutatásaim majdnem teljesen lefedték az „elméletet”, ami újabb bizonyíték a több millió éve „bennünk élő” sajátosság aktív meglétére.

A létszámfüggő funkcionális organizációk sajnos már nem mindig tanúskodnak ilyen tökéletes ,illeszkedésrôl". (Itt jegyzem meg, hogy a genetikai örökségünkhöz minél jobban igazodó csoport- és szervezeti létszámok kialakítása például egy kiváló lehetőség a humánetológiai kutatások eredményeinek gyakorlati hasznosítására.)

A néha meglepő eredményekkel szolgáló érzelmi és viselkedési szinkronizáció az ember esetében olyan biológiai alapú készség, melynek munkahelyi körülmények között is jelentős szerepe van. A különféle mechanizmusok által megvalósuló nagyfokú szinkronizáció a kollégákból csodálatos összhangban működő csoportot képes teremteni, mely annak teljesítményét I 2 és légkörét gyakran az átlag fölé emeli.
Az agresszió munkahelyi körülményekre kidolgozott rendszerezésén alapuló vizsgálataim meglehetősen sokféle és különböző formában felszínre törő viselkedésformát konstatáltak. Bár ezek többnyire burkoltan vagy enyhe formában jelentkeznek, a rájuk való odafigyelés, valamint olykor elengedhetetlen kezelésük, sokszor kihívást jelentő vezetői feladat lehet.

$\mathrm{Az}$ egyik legkomplexebb kutatási részterület a rangsor, a dominancia és a szabálykövetés hármasát elemző vizsgálataim a vezetői tulajdonságokat, illetve azok beosztottakra gyakorolt hatását boncolgatták.

Megállapítást nyert, hogy a genetikai örökségen alapuló pozíció-elfogadás a státusért folytatott küzdelem mellett jelentkezik. A folyamatos szakmai fejlődés és az emberi kapcsolatok ápolása gyakran az egyén munkahelyi dominanciájának növekedését eredményezi.

Az informális vezetővé váláshoz szükséges tényezők, viselkedésjegyek feltérképezése után figyelmem a szabálykövetés vizsgálatára irányult.

Fajunk szabálykövető természete a munkáját szervezeti körülmények között végző kollégáknál rendkívül erősen kimutatható. Ezt a legkülönfélébb szituációkban megfigyelhető alávetési és engedelmességi megnyilvánulások sora igazolja.

Úgy gondolom, hogy a kutatási területek eredményeit - a maguk komplexitásában - olyan ,befolyásolási zónák"-ként lehet a gyakorlatban leginkább hasznosítani, ahol például egy vezetési, szervezetfejlesztési vagy konfliktusmenedzsmenttel kapcsolatos probléma megoldásához olyan humánetológiai aspektusú eredményekkel szolgálhatok, melyek figyelembevételével nemcsak egy hatékonyabb, hanem egy kellemesebb légkörü teamhez, szervezethez juthatunk.

Ehhez az alapötletet az adta, hogy ha az emberi természetnek léteznek velünk született, evolúciós örökségen alapuló komponensei - márpedig ezek megléte tény -, akkor miért ne vehetnénk, vennénk azokat figyelembe annak érdekében, hogy a természethez - így önmagunkhoz -, illetve az öröklött tulajdonságainkhoz való igazodással nagyobb harmóniát biztosítsunk kollégáink, s általuk egyben az egész szervezetünk számára is. Az ily módon megvalósuló harmónia pedig a hierarchiai viszonyoktól függetlenül minden, a közösség érdekében tevékenykedő dolgozóra kifejti majd jótékony hatását.

Általános recept, pontról-pontra követendő szabály természetesen nincs. Ez már csak azért is így van, mert minden szituáció más és más, valamint az anyagi, jogi stb. korlátok is gyakran megkötik egy vezető(ség) kezét, mikor szervezetalapításhoz vagy szervezetalakí- 
A kutatási területek és a releváns vezetési tevékenységek gyakorlati adaptációs logikai kapcsolat-mátrixa

\begin{tabular}{|c|c|c|c|c|c|c|}
\hline $\begin{array}{l}\text { Kutatási } \\
\text { területek } \\
\text { Vezetési tev. }\end{array}$ & Kontaktusok & $\begin{array}{c}\text { Kötődési } \\
\text { kapcsolatok }\end{array}$ & Csoportszerkezet & Szinkronizáció & Agresszió & $\begin{array}{c}\text { Rangsor, } \\
\text { dominancia, és } \\
\text { szabálykövetés }\end{array}$ \\
\hline Vezetéslélektan & $\begin{array}{l}\text { - különféle kon- } \\
\text { taktus-formák } \\
\text { pszichológiai } \\
\text { hatásai, } \\
\text { - szociális attitű- } \\
\text { dök, } \\
\text { - vezetői test- } \\
\text { beszéd tudatos } \\
\text { alkalmazása (!) }\end{array}$ & $\begin{array}{l}\text { - férfi-nôi pre- } \\
\text { desztináltság } \\
\text { viselkedési } \\
\text { sajátosságai, } \\
\text { - férfikötődés } \\
\text { lélektani hatá- } \\
\text { sai }\end{array}$ & $\begin{array}{l}\text { - csoporthoz való } \\
\text { tartozás pszi- } \\
\text { chikai tényezői } \\
\text { - csoportméret } \\
\text { egyénre gyako- } \\
\text { rolt lélektani } \\
\text { hatásai }\end{array}$ & $\begin{array}{l}\text { - lélektani szink- } \\
\text { ronizációs me- } \\
\text { chanizmusok } \\
\text { - szubmissziós } \\
\text { készség } \\
\text { - egyéni szinkro- } \\
\text { nizációs ténye- } \\
\text { zők } \\
\text { - hangulati hatá- } \\
\text { sok }\end{array}$ & $\begin{array}{l}\text { - az agresszió } \\
\text { léleletani } \\
\text { gyökerei } \\
\text { - munkahelyi } \\
\text { agresszió fajtái, } \\
\text { jellegzetességei } \\
\text { - agresszív } \\
\text { magatartásfor- } \\
\text { mák azonosítá- } \\
\text { sa, kezelése }\end{array}$ & $\begin{array}{l}\text { - egyéni törekvé- } \\
\text { sek lélektani } \\
\text { háttere } \\
\text { - pozíció- és sza- } \\
\text { bály-attitű́dök } \\
\text { feltárása és ke- } \\
\text { zelése } \\
\text { - informális ve- } \\
\text { zetővé válás } \\
\text { filogeneteikai } \\
\text { jellemzői }\end{array}$ \\
\hline „Coaching” & $\begin{array}{l}\text { - megfelelő kon- } \\
\text { taktusformák } \\
\text { alkalmazása } \\
\text { - evolúciós ala- } \\
\text { pokra helyezett } \\
\text { motiváció }\end{array}$ & $\begin{array}{l}\text { a nemek filoge- } \\
\text { netikai jelleg- } \\
\text { zetességeinek } \\
\text { figyelembevéte } \\
\text { le az ,edzés” } \\
\text { során }\end{array}$ & $\begin{array}{l}\text { - optimális cso- } \\
\text { portszerkezet } \\
\text { és -méret ki- } \\
\text { alakítása a di- } \\
\text { namikus egyé- } \\
\text { ni, és kollektív } \\
\text { fejlődés érde- } \\
\text { kében }\end{array}$ & $\begin{array}{l}\text { szinkronizá- } \\
\text { ciós tényezők } \\
\text { ambíciót növe- } \\
\text { lő hatásának } \\
\text { kihasználása } \\
\text { - csoport- } \\
\text { szinkronizációs } \\
\text { mechanizmu- } \\
\text { sok }\end{array}$ & $\begin{array}{l}\text { - agresszió csil- } \\
\text { lapítása a biza- } \\
\text { lom és védett- } \\
\text { ség légkörének } \\
\text { megteremtése } \\
\text { érdekében }\end{array}$ & $\begin{array}{l}\text { - egyéni ambí- } \\
\text { ciók szervezeti } \\
\text { célokkal való } \\
\text { harmonizációjá } \\
\text { nak megterem- } \\
\text { tése } \\
\text { - a kommuniká- } \\
\text { ció és a sza- } \\
\text { bálykövetés kö- } \\
\text { zötti kapcsolat } \\
\text { sajátosságai }\end{array}$ \\
\hline $\begin{array}{l}\text { Konfliktus- } \\
\text { kezelés }\end{array}$ & $\begin{array}{l}\text { - kontaktusok } \\
\text { megnyilvánulási } \\
\text { lehetőségeinek } \\
\text { biztosítása } \\
\text { - vezetői mentá- } \\
\text { lis, verbális és } \\
\text { fizikai kontak- } \\
\text { tusok lélektani } \\
\text { hatásai }\end{array}$ & $\begin{array}{l}\text { - a férfikötődés } \\
\text { és dominancia } \\
\text { evolúciógeneti- } \\
\text { kai hátterének } \\
\text { ismerete } \\
\text { - férfi és női ve- } \\
\text { zetők tipikus } \\
\text { jellemzổinek } \\
\text { szem előtt tar- } \\
\text { tása }\end{array}$ & $\begin{array}{l}\text { - a természetünk- } \\
\text { höz jobban il- } \\
\text { leszkedő lét- } \\
\text { számfüggő́ } \\
\text { funkcionális } \\
\text { csoport-organi- } \\
\text { zációk kialakí- } \\
\text { tása }\end{array}$ & $\begin{array}{l}\text { - szinkronizációt } \\
\text { elősegítô, nö- } \\
\text { velő tényezők } \\
\text { vezetői alkal- } \\
\text { mazása } \\
\text { - vezetői akarat- } \\
\text { átvitel szinkro- } \\
\text { nizációval } \\
\text { történő segítése }\end{array}$ & $\begin{array}{l}\text { konfliktusok } \\
\text { agresszió-kate- } \\
\text { góriákra lebon- } \\
\text { tott vizsgálata, } \\
\text { - a pontos ok-fel- } \\
\text { tárás hatékony } \\
\text { konfliktuskeze- } \\
\text { lést tesz lehető- } \\
\text { vé. }\end{array}$ & $\begin{array}{l}\text { - eredményes ve- } \\
\text { zetői konflik- } \\
\text { tuskezelés az } \\
\text { emberi termé- } \\
\text { szet rangsorra, } \\
\text { dominanciára } \\
\text { és szabályköve- } \\
\text { tésre vonatkozó } \\
\text { sajátosságainak } \\
\text { ismeretében }\end{array}$ \\
\hline $\begin{array}{l}\text { Szervezet- } \\
\text { alakítás }\end{array}$ & $\begin{array}{l}\text { - az emberi ter- } \\
\text { mészet kontak- } \\
\text { tusigényéhez } \\
\text { igazodó szerve- } \\
\text { zet kialakítása, } \\
\text { - kontaktusalapú } \\
\text { rendezőelvek } \\
\text { alkalmazása }\end{array}$ & $\begin{array}{l}\text { - a férfikötődés } \\
\text { révén kialakult } \\
\text { „informális” } \\
\text { csoportok eset- } \\
\text { leges formális } \\
\text { transzformációja } \\
\text { - férfi-női jelleg- } \\
\text { zetességek } \\
\text { előnyös kihasz- } \\
\text { nálása }\end{array}$ & $\begin{array}{l}\text { - a genetikai hát- } \\
\text { tér és a feladat } \\
\text { jellemzői alap- } \\
\text { ján kialakítan- } \\
\text { dó szervezeti } \\
\text { egység-létszá- } \\
\text { mok hatékony- } \\
\text { ság- és jó köz- } \\
\text { érzet biztosító } \\
\text { hatása }\end{array}$ & $\begin{array}{l}\text { - szinkronizációs } \\
\text { elemek tudatos } \\
\text { vezetői beépí- } \\
\text { tése az ösztön- } \\
\text { zési, képzési, } \\
\text { és személyzeti } \\
\text { alrendszerekbe, } \\
\text { - a szervezettel } \\
\text { való azonosulás } \\
\text { szinkronizáció } \\
\text { általi erősítése }\end{array}$ & $\begin{array}{l}\text { - már a tervezés } \\
\text { fázisában kör- } \\
\text { vonalazható } \\
\text { jövőbeli ag- } \\
\text { resszió-formák } \\
\text { - agresszív meg- } \\
\text { nyilvánulások } \\
\text { tervezhetố ke- } \\
\text { zelése }\end{array}$ & $\begin{array}{l}\text { - informális ve- } \\
\text { zetők korai fel- } \\
\text { ismerése, majd } \\
\text { formai kiszer- } \\
\text { vezéssel való } \\
\text { támogatásuk, } \\
\text { - az új szabályok } \\
\text { megfelelố kom- } \\
\text { munikációja } \\
\text { jelentôsen nö- } \\
\text { veli a vezetett } \\
\text { szabálykövetổ } \\
\text { hajlandóságát }\end{array}$ \\
\hline $\begin{array}{l}\text { Változás- } \\
\text { vezetés }\end{array}$ & $\begin{array}{l}\text { - a kontaktusok } \\
\text { folyamatos } \\
\text { szondázása (ve- } \\
\text { zetối visszacsa- } \\
\text { tolás) } \\
\text { - a kontaktusok- } \\
\text { ból származó } \\
\text { pozitív érzel- } \\
\text { mek serkentổ } \\
\text { hatásának veze- } \\
\text { tői kihasználása } \\
\text { (változás mellé } \\
\text { állítás) }\end{array}$ & $\begin{array}{l}\text { - a változással } \\
\text { szembeni ellen- } \\
\text { állás leküzdé- } \\
\text { sének hatékony } \\
\text { eszköze lehet a } \\
\text { nemek eltéró } \\
\text { tulajdonságinak } \\
\text { a kihasználása }\end{array}$ & $\begin{array}{l}\text { - változást irá- } \\
\text { nyító csapat } \\
\text { létrehozása az } \\
\text { evolúciós örök- } \\
\text { ségünkhöz iga- } \\
\text { zodó létszámin- } \\
\text { tervallumok fi- } \\
\text { gyelembevéte- } \\
\text { lével } \\
\text { - a változással } \\
\text { érintett csopor- } \\
\text { tok létszámá- } \\
\text { nak meghatá- } \\
\text { rozása }\end{array}$ & $\begin{array}{l}\text { - szinkronizáció } \\
\text { szándékos ve- } \\
\text { zetői csökken- } \\
\text { tése a változ- } \\
\text { tatni kívánt te- } \\
\text { rületeken } \\
\text { - a kivívott ered- } \\
\text { mények szink- } \\
\text { ronizációval } \\
\text { támogatott } \\
\text { megszilárdítása }\end{array}$ & $\begin{array}{l}\text { - a változással } \\
\text { kapcsolatos } \\
\text { emberi reak- } \\
\text { ciók előrejelzé- } \\
\text { se és kezelése, } \\
\text { - az agressziót } \\
\text { csillapító (eset- } \\
\text { leg erôsítô) ve- } \\
\text { zetői beavatko- } \\
\text { zás }\end{array}$ & $\begin{array}{l}\text { - az emberi ter- } \\
\text { mészet sajátos- } \\
\text { ságaira épülő } \\
\text { vezetői taktika } \\
\text { és manipuláció } \\
\text { alkalmazása, } \\
\text { - a vezetói ma- } \\
\text { gatartás mozga- } \\
\text { tórugóinak vi- } \\
\text { lágosabb átlátá- } \\
\text { sa }\end{array}$ \\
\hline
\end{tabular}


djsil latban is kitapinthatóvá válik.

Az előzőek alapján kidolgoztam a változásvezetés, o s a konfliktuskezelés és a „coaching” viselkedéscentw’ilin rikus, többfázisú sorrend-helyes modelljét, melyek todふ̀̀ vábbi részletezése - a vázolt gondolatmenet logikája ఫs Is alapján - egy konkrét beavatkozási folyamatra némi isøv vezetői gyakorlattal, viselkedéskutatási, illetve veze- tés-lélektani ismeretek birtokában, kis kreativitással könnyen elvégezhető.

Bízom benne, hogy az általam lefektetett úton továbbhaladva hazai és nemzetközi kutatók hasonló módon modellek tucatjait, illetve azok egymásra épülő komplex rendszerét építhetik fel, mellyel az utóbbi időben talán kissé lelassult vezetéstudományi fejlődés újabb lendületet vehet.

A konkrét eredmények tételes bemutatására jelen írásban terjedelmi okokból nem vállalkozhattam, így a célom sem ez volt, pusztán a figyelmet szeretném ráirányítani az új megközelítésre, mellyel eddig ebben a formában sem a hazai, sem a külföldi szakirodalomban nem találkoztam.

Remélem, hogy eddigi vizsgálataim egy hosszú lánc első szemét jelentik csupán, s az így kapott eredmények azoknak a további kutatásoknak az alapját fektetik le, melyek konklúziói újabb szintetikus megállapítások elôtt nyitnak majd kaput.

Végezetül azon reményemnek szeretnék hangot adni, amely a vezetéstudomány forradalmian új megközelítése és gyakorlatba való átültetése révén nem csak vezetők és vezetettek, hanem áttételesen családok, sőt akár egész társadalmak életét teheti boldogabbá és harmonikusabbá, hozzájárulva ezzel az emberiség jövőbe vetett hitének beteljesüléséhez ...

\section{Felhasznált irodalom}

Csányi, V. (2000): Az emberi természet, Humánetológia. Vince Kiadó, Budapest

Eibl-Eibesfeldt, I. (1989): Human Ethology. Aldine de Gruyter, New York

Forgács, J. (2000): A társas érintkezés pszichológiája. Gondolat Kairosz, Budapest

Klein, S. (2002): Vezetés- és szervezetpszichológia. Edge 2000, Budapest 